https://doi.org/10.28925/2226-3012.2021.106

УДК: 378.22:616.31-051:005.336.2

\title{
Ірина Скрипник,
}

ORCID iD 0000-00023-3393-4649

кандидат медичних наук, доцент

кафедри ортодонтії та пропедевтики ортопедичної стоматології,

Національний медичний університет імені О. О. Богомольця,

бульвар Т. Шевченка 13, 01601 Київ, Україна,

irynaskrypnyk@gmail.com

\section{Ярослава Кульбашна,}

ORCID iD 0000-0002-2571-091X

доктор педагогічних наук, кандидат медичних наук, професор,

професор кафедри хірургічної стоматології та щелепно-лицевої хірургії,

Національний медичний університет імені О. О. Богомольця,

бульвар Т. Шевченка 13, 01601 Київ, Україна,

j.kulbashna@gmail.com

\section{Валерія Захарова,}

ORCID iD 0000-0002-8863-2373

кандидат педагогічних наук, викладач кафедри іноземних мов,

Національний медичний університет імені О. О. Богомольця,

бульвар Т. Шевченка 13, 01601 Київ, Україна,

valerieozakharova@gmail.com

\section{ФОРМУВАННЯ ПРАКСЕОЛОГІЧНОЇ КОМПЕТЕНТНОСТІ МАГІСТРІВ СТОМАТОЛОГІЇ: МОТИВАЦІЙНА СКЛАДОВА}

У статті розкрито зміст, визначено компоненти і етапи розвитку мотиваційної готовності майбутніх магістрів стоматології до професійної діяльності у контексті формування праксеологічної компетентності. Надано визначення поняттю мотивачійна готовність майбутніх магістрів стоматології до професійної діяльності як динамічне особистісне утворення, яке характеризується сформованістю професійно важливих якостей, усталеністю внутрішніх мотивів до вибору професії і кінцевих цілей професійної підготовки та зовнішніх - привабливість професії у контексті життєзабезпечення особистості і фахової самореалізації. Охарактеризовано компоненти мотиваційної готовності майбутніх магістрів стоматології, зокрема представлені результати опитування серед випускників стоматологічного факультету НМУ імені О.О. Богомольия, що визначили комплекс мотивів, які сприяють формуванню готовності до виконання практичної діяльності. Розкрито орієнтачійний, синергетичний та коригуючий етапи мотиваційної готовності майбутніх магістрів стоматології. Доведено, що наявність стійких професійних мотивів у майбутніх стоматологів сприяє успішному оволодінню ними майбутньою професійною діяльністю і формуванню мотиваційної готовності до неї.

Ключові слова: мотивачійна готовність; праксеологічна компетентність; професійна діяльність; професійна самореалізація; фахові компетентності.

(с) Скрипник Ірина, Кульбашна Ярослава, Захарова Валерія, 2021

Вступ. Проблема підготовки компетентного лікаря залишається актуальною у сучасному суспільстві. Нові виклики, з якими зустрічається людство суттєво розширяють межі про- фесійної активності і поглиблюють відповідальність фахівця 3 медичною освітою. Так, часи пандемії 2020-2021 рр. продемонстрували, що спеціалісти різних профілів залуча- 
ються до діяльності, не притаманної їньому фаху (наприклад, залучення невропатологів, офтальмологів, оторінолярінгологів, щелепнолицевих хірургів та ін. до надання допомоги хворим на COVID-інфекцію). Уможливлює подібні трансформації упроваджена у медичну освіту компетентнісна парадигма, яка внесла суттєві корективи до професійної підготовки майбутніх лікарів, які повинні демонструвати високий рівень компетентності і реалізувати свої знання на практиці, адаптуватися до швидкоплинних змін і умов професійної діяльності. Значною мірою досягненню цієї мети сприяють світоглядні і мотиваційні чинники при обранні професії, які у процесі навчання у медичному закладі вищої освіти формуються у готовність до виконання нетипових професійних завдань відповідно до набутого рівня професійної компетентності випускника. Великого значення у цьому контексті набуває формування психологічної, зокрема, мотиваційної готовності студента до майбутньої професійної діяльності у праксеологічному контексті, як одному iз базових компонентів професійної компетентності лікаря (Кульбашна, 2014).

Проблема мотиваційної готовності до професійної діяльності у психолого-педагогічній літературі розглядається науковцями через призму особливостей професійної підготовки фахівців різних спеціальностей та специфічних видів діяльності. Науковці встановили пряму залежність результативності підготовки фахівців від сформованості мотиваційної сфери особистості студента, яка проявляється у мотиваційній готовності до професійної діяльності (Клімова, 2014). Праксеологічний контекст цієї проблеми полягає у свідомому визначенні майбутнім лікарем мотивів, які спонукають до вибору фаху, досконалого освоєння його практичних аспектів, розширенню кола інтересів і появою потреби до їх успішної реалізації у професійній діяльності.

Аналіз наукових джерел (Field, Cowpe, Walmsley, 2017; Harzer, Tausche, Gedrange, 2015; Reynolds, Eaton, Paganelli, Shanley, 2008) вказує, що мотиваційна складова визначається науковцями у структурі професійної компетентності лікаря-стоматолога та спеціальних компетентностей, що актуалізує дослідження мотиваційної готовності майбутніх магістрів стоматології до професійної діяльності, значну частину якої охоплює практична робота з пацієнтами, забезпечена праксеологічною компетентністю.

Мета: розкрити зміст, визначити компоненти та етапи розвитку мотиваційної готов- ності майбутніх магістрів стоматології, до професійної діяльності у контексті формування праксеологічної компетентності.

Зміст поняття «мотиваційна готовність» майбутніх магістрів стоматологіi. Науковці доводять, що високий рівень професіоналізму, активність, творчість тощо, визначаються особливостями мотиваційної сфери особистості, зокрема - мотиваційною готовністю до діяльності (Клімова, 2014). Незважаючи на те, що у 2020-2021 рр. освітній простір, зокрема і медичних 3ВО, зазнав суттєвих організаційних змін (на перший план вийшла дистанційна

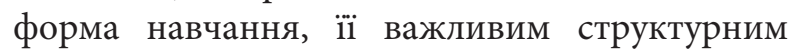
елементом для здобувачів вищої освіти став високий рівень освітньої самомотивації і самостійної роботи (Корда, Шульгай, Машталір, Чорномидз, 2021).

Адекватну мотивацію у виборі фаху, усвідомлення його цінностей i кінцевої мети можна вважати наріжним каменем майбутнього успішного професійного розвитку лікаря та його діяльності оскільки його робота пов'язана 3 екстраординарними ситуаціями, часом, розчаруваннями, усвідомленням тонкої межі між життям, хворобою та смертю, місцем лікаря в цьому процесі. Відтак, важливу роль, серед інших, у формуванні готовності до професійної діяльності, грає мотиваційна сфера майбутнього лікаря, яка забезпечить їі мотиваційну складову зокрема і у праксеологічному аспекті - надзвичайно важливому для лікарястоматолога (Кульбашна, Скрипник, 2020). Відомо, що формування праксеологічної компетентності майбутніх магістрів стоматології, як складової професійної компетентності забезпечується мотивами, які у майбутнього фахівця виникають при вступі до медичного ЗВО. Мотиваційну готовність формують мотиви, інтереси, потреби, які у процесі навчання можуть набувати динамічних змін (Кульбашна, 2014; Ali, Slade, Kay, Zahra, Tredwin, 2017).

Понятійно-термінологічний комплекс 3 проблеми дослідження мотиваційної готовності до професійної діяльності майбутніх медичних працівників представлено у нечисельних наукових джерелах (Емельяненко, 2011; Гуртовенко, 2014; Клімова, 2014; Кульбашна, 2014). Термін «готовність» розглядається педагогами та психологами як системне особистісне утворення; стан; якість особистості; синтез певних особистісних якостей; (Емельяненко, 2011), як приведення в активний стан усіх психофізіологічних систем людського організму, необ- 
хідних для ефективного виконання певних дій (Клімова, 2014). «Готовність до діяльності» визначається водночас як психічний стан і як якість особистості. Вона є об'єктивною передумовою і умовою ефективної діяльності людини, яка формується тільки у іiі процесі. Поняття «готовність» у контексті професійної діяльності починається, як зазначає Н. Гуртовенко (Гуртовенко, 2014), з психологічної готовності iii розпочати, забезпечуючи можливість самореалізації. Значущість психологічної готовності до діяльності визначається подоланням психологічного бар'єру, що, на думку британських науковців (Ali, Slade, Kay, Zahra, Tredwin, 2017), $€$ одним із важливих чинників у роботі лікарястоматолога. Сформована готовність до професійної діяльності визначається психологічною готовністю, у якій найбільш значущою підструктурою є мотиваційна складова, як вказують Л.М. Ємельяненко (Емельяненко, 2011), Д.В. Клімова (Клімова, 2014), О.В. Коваленко (Коваленко, 2020), оскільки розвиток та реалізація інструментальних властивостей фахівця можуть бути ефективними лише за умови ї концентрування навколо мотиваційного ядра особистості, його професійно-значущої спрямованості (Клімова, 2014).

Мотиваційна готовність до професійної діяльності, на думку Д.В. Клімової (Клімова, 2014), пов'язана зі специфікою фахової підготовки і визначається як усвідомлений, активнодіяльнісний стан, який забезпечує особистісну й професійну самореалізацію та самоактуалізацію під час вирішення професійних проблем на основі особистісного та професійного досвіду, творчого використання індивідуальнопсихічних особливостей та інтелектуального потенціалу в процесі професійної діяльності. Водночас Л. М. Ємельяненко (2011) розглядає їі як цілісну, відносно стійку систему психічних утворень особистості, які, у процесі актуалізації у певних обставинах створюють відповідні стани психіки і спонукають, регулюють поведінку і діяльність людини, як цілісне особистісне утворення, яке характеризується сукупністю зовнішніх і внутрішніх мотивів, а для медпрацівників - як цілісне структурне утворення особистості, яке визначає направленість на здійснення медичної діяльності, забезпечення ефективної професійної адаптаціï, самореалізацію і саморозвиток випускника. Вчена відзначає, що процес формування мотиваційної готовності тривалий і динамічний, а іiі сутність розкривається через такі категорії: мотив, інтерес, цінності, здібності, які визначають спроможність до відповідного фаху, а основним чинником є розуміння сенсу своєї професії, позитивне ставлення до неї, достатній рівень самооцінки і домагань у діяльності. Формування мотиваційної готовності до діяльності пов'язане 3 навчальною мотивацією, але важливо відзначити можливі відмінності у цілях, проте тільки їх єдність забезпечує високий рівень готовності. У процесі професійної підготовки фахівця формуються базові чинники - інтереси, здібності, моральні принципи, установки, самооцінка та інше, формування яких $є$ завданням педагогіки. У такий спосіб під впливом зовнішніх факторів, на думку Л.М. Ємельяненко (2011) набуває розвитку мотиваційна сфера особистості медичного працівника.

Основні компоненти мотиваційної готовності майбутніх магістрів стоматології. Одним iз компонентів мотиваційної готовності $€$ феномен мотивації. Мотивація у психологопедагогічних наукових джерелах розглядається, зокрема, як фактор впливу на формування професійної спрямованості студентів закладів вищої освіти, що уособлює одне з головних рішень у житті кожного індивіда, становить основу самоствердження (Коваленко, Боброва, Ганчо, Зачепіло, 2020). Водночас Н.В. Гуртовенко (2014), зазначає, що мотивація об’єднує навчально-професійну та професійну діяльність.

Під мотивацією розуміють (Коваленко, 2020) сукупність спонукаючих чинників, що визначають активність особистості, до яких належать мотиви, стимули, ситуативні чинники, потреби, що детермінують поведінку людини. Мотиваційна сфера будь-якої діяльності виконує ряд функцій: спонукаючу (викликає активність людини до діяльності); спрямовуючу (визначає характер мети в діяльності); регулюючу (визначає ціннісні орієнтації, мотиви діяльності).

Мотивація є досить складним процесом, що може мати різне спрямування. Внутрішня мотивація знаходиться в самій людині і $є$ більш значущою, ефективною i необхідною формою мотивації. Зовнішня мотивація виходить від батьків, педагогів, суспільства (Коваленко, 2020).

Виокремлюють 5 основних мотивів навчальної діяльності студентів медичних 3ВО: стати висококваліфікованим спеціалістом - 68,8 \%, отримати диплом - 64 \%, набути глибоких 
та міцних знань - 48 \%, отримати інтелектуальне задоволення - 43,2 \%, забезпечити успішність майбутньої професійної діяльності 40 \%. Крім того, більшість опитаних студентів виділяє позитивним мотиваційним аспектом отримання схвалення і похвали від колег і викладачів (Кульбашна, 2014). Так, для формування мотиваційної готовності необхідно переважно стимулювати внутрішні мотиви.

Мотиваційний компонент психологічної готовності забезпечує ініціацію процесу професійно-управлінського самовизначення та динаміку його розгортання і включає, насамперед, потребу в професійному самовизначенні.

Варто відзначити думку Л.М. Ємельяненко (2011), яка стверджує, що мотиваційна готовність виявляється у професійній спрямованості на успішну медичну діяльність, а формування мотиваційної готовності у медичних працівників розвивається поетапно, шляхом удосконалення і постановки перед собою все більш значущих цілей і задач, мотиви змінюються, що впливає і на рівень мотиваційної готовності. Базовим компонентом мотивації визначено «мотиви», які у професійній діяльності виступають головним чинником професійної спрямованості студентів і подальшої ефективної фахової діяльності. Мотивам, які входять до складу професійної спрямованості майбутнього магістра стоматології, притаманна динамічна зміна їх пріоритетності та полімотиваційність (Ali, Slade, Kay, Zahra, Tredwin, 2017; Field, Cowpe, Walmsley, 2017). Мотивація відображає дії особистості з реалізації мотивів, які виступають причинами дій, а мотивація $є$ їнім наслідком. Мотиви до виконання будь-якої професійної діяльності конкретизуються потребами індивіда, а вони, у свою чергу наповнюють мотиви відповідним змістом. На мотиви, які формують професійну спрямованість впливають об'єктивні та суб'єктивні фактори, оскільки потреби мають індивідуальні відмінності, залежать від віку, інтелектуального, морального, емоційного розвитку, життєвих ситуацій (Гуртовенко, 2014), а джерелом мотивів професійної спрямованості виступають потреби, які відображають матеріальну, соціальну, духовну складові особистості. Аналіз наукових вітчизняних i зарубіжних джерел (Емельяненко, 2011; Гуртовенко, 2014; Клімова, 2014; Коваленко та ін., 2020; Корда та ін., 2021; Harzer, Tausche, Gedrange, 2015; Field, Cowpe, Walmsley, 2017) дає змогу зробити висновок, що на сьогодні існує багато теорій, що намага- ються пояснити мотиваційні фактори, які спонукають до професійної діяльності. Серед найбільш істотних мотивів, що входять до складу професійної спрямованості найбільш суттєвими є: зміст професійної діяльності, заробітна плата, можливість підвищення кваліфікаційного рівня. Професійна спрямованість завжди полімотивна i зумовлена співвідношенням рівня матеріальної зацікавленості в професійній діяльності, інтересом до неї та соціальною цінністю результату.

Необхідно зазначити, що позитивна мотивація до навчальної діяльності студентів залежить, на думку Н. В. Гуртовенко (2014), від професійної спрямованості навчальної діяльності, застосування різноманітних активних форм і методів навчання, компетентності викладача. Саме організація і методика викладання предметів впливають на формування у студентів позитивного мотиву до навчання, а відтак і на майбутню фахову діяльність, в усвідомленні кінцевих цілей навчання; теоретичної і практичної значущості засвоюваних знань; демонстрації «перспективних ліній»; професійної спрямованості навчальної діяльності; моделюванні і вирішенні проблемних ситуацій, що можуть виникати в процесі професійної діяльності. Зокрема, у контексті формування праксеологічної компетентності майбутніх магістрів стоматології актуалізується екстраполяція умінь, засвоєних у симуляційному форматі в умовах клініки.

Аналіз праць науковців із проблеми дослідження мотиваційної готовності майбутніх фахівців різних галузей, проведений Д. В. Клімовою (2014) свідчить, що науковці виділяють такі базові компоненти мотиваційної готовності: позитивне ставлення, інтерес суб’єкта до своєї професії, орієнтація на мотиви та цінності обраної професійної діяльності, потреба в ній, а також потреба в досягненнях і самовдосконаленні, задоволеність здійсненим професійним вибором, професійна самовизначеність, бажання працювати у майбутньому за фахом, що мотивується зацікавленістю змістом власної професійної діяльності; сформований комплекс стійких мотивів. Учена визначає мотиваційну готовність до професійної діяльності як усвідомлений та активно-діяльнісний стан, який забезпечує особистісну й професійну самореалізацію та самоактуалізацію під час вирішення професійних проблем на основі психолого-педагогічної компетентності, особистісного та професійного досвіду, творчого 
використання індивідуально-психічних особливостей та інтелектуального потенціалу в процесі професійної діяльності. Важливим є, на думку Л. М. Ємельяненко (2011), визначення рівня мотиваційної готовності як міри відповідності спроможності особистості контролювати і коригувати свою активність, систему мотивів, цінностей у відповідності до існуючих умов і вимог. Для його визначення необхідна розробка відповідних показників і критеріїв, визначення етапів і шляхів впливу на процес.

Аналіз наукових джерел (Кульбашна, 2014; Коваленко та ін., 2020; Корда та ін, 2021; Harzer, Tausche, Gedrange, 2015; Reynolds, Eaton, Paganelli, Shanley, 2008; Ali, Slade, Kay, Zahra, Tredwin, 2017; Field, Cowpe, Walmsley, 2017) свідчить, що підготовка компетентного випускника медичного закладу вищої освіти передбачає формування його мотиваційної готовності до професійної діяльності, однією із складових якої
$€$ праксеологічний компонент, який охоплює практичну частину цієї діяльності від організації до реалізації знань і умінь. Успішна практична діяльність лікаря-стоматолога потребує сформованості мотиваційної готовності у глибокому розумінні праксеологічного змісту.

Для визначення комплексу мотивів, які сприяють формуванню мотиваційної сфери майбутніх магістрів стоматології і їхньої мотиваційної готовності до виконання практичної діяльності проведено анонімне опитування за раніше розробленою анкетою серед випускників стоматологічного факультету НМУ імені Богомольця за 2019 - 2020 рр. (всього 135 осіб) та порівняння 3 результатами аналогічного дослідження у 2015 р. (Кульбашна, 2015). Мотиви, які досліджувались, виокремлено у блоки: Фундаментальні: цзннісно-світоглядні та кар'єрно-комериійні.

Отримані результати представлені в Таблиці 1.

Таблиия 1

Порівняльний аналіз мотивів професійної підготовки майбутніх лікарів-стоматологів

\begin{tabular}{|c|c|c|}
\hline \multirow{2}{*}{ Мотиви } & \multicolumn{2}{|c|}{ Відповіді ( у \%) } \\
\hline & 2020 & 2015 \\
\hline \multicolumn{3}{|l|}{ Фундаментальні: изіннісно-світоглядні } \\
\hline $\begin{array}{l}\text { А. Вирішення глобальних проблем практичної стоматологічної діяльності, } \\
\text { розробка і упровадження інновацій на базі доказової медицини і науково- } \\
\text { технічних досягнень }\end{array}$ & 37,5 & 13 \\
\hline Б. Моральне задоволення від роботи лікаря & 48,2 & 47 \\
\hline $\begin{array}{l}\text { B-Є. Бажання працювати в органах управління охорони з метою контролю } \\
\text { i оптимізації якості надання стоматологічної допомоги населенню }\end{array}$ & 32,1 & 5,9 \\
\hline Г-Ж- сімейні традиції & 27 & \\
\hline \multicolumn{3}{|l|}{ кар’єрно-комериійні } \\
\hline Д-В. Матеріальна зацікавленість у професійній діяльності & 39,2 & 42 \\
\hline Е-Г. Розбудова власного бізнесу (приватна практика) (клініка/кабінет) & 39,2 & 36 \\
\hline Є-Д. Перспектива практичної роботи за кордоном за контрактом & 41 & 12,7 \\
\hline $\begin{array}{l}\text { Ж-Е. Перспектива подальшої еміграції і працевлаштування за фахом в інших } \\
\text { країнах }\end{array}$ & 21,4 & 23,6 \\
\hline
\end{tabular}

Аналіз таблиці 1 засвідчив, що найбільш динамічні позитивні зміни спостерігаються щодо ціннісно-світоглядних мотивів; бажання вирішувати глобальні проблеми практичної стоматологічної діяльності. Розробляти та упроваджувати інновації на базі доказової медицини і науково-технічних досягнень виявили майже втричі більше опитаних та кількість осіб спрямованих на підвищення рівня надання медичної допомоги через управлінські рішення зросло майже у 5 разів. Практично стабільно половина опитаних вважає принципово важливим отримувати моральну насолоду від своєї роботи. Поряд з тим, виявилися і нега- тивні тенденції - число тих, кого привабила перспектива подальшої реалізації за кордоном зросло більше, ніж утричі, що прямо вказує на загрозу суттєвого відтоку медичних кадрів з України. Детальнішу інтерпретацію отриманих даних доцільно провести після поглибленого вивчення даного питання після завершення періоду онлайн навчання.

Переважна більшість опитаних (близько половини) розглядали вибір фаху стоматолога всебічно, полімотиваційно, а $34 \%$ з них зазначили, що у процесі навчання мотиви конкретизувалися, що свідчить про відповідальний та свідомий підхід більшості майбутніх стома- 
тологів до формування мотивації до навчання з метою максимально оволодіти фахом, зокрема і у частині практичної діяльності.

Результати аналізу наукових джерел дали змогу визначити мотиваційну готовність майбутніх магістрів стоматології до професійної діяльності у контексті формування праксеологічної компетентності як динамічне особистісне утворення, яке характеризується сформованістю професійно важливих якостей, усталеністю внутрішніх мотивів до вибору професії і кінцевих цілей професійної підготовки та зовнішніх - привабливість професії у контексті життєзабезпечення особистості і фахової самореалізаціі.

Основні етапи формування мотиваційної готовності майбутніх магістрів стоматології. Зважаючи на тривалість професійної підготовки протягом майбутніх магістрів стоматології п'яти шести років (відповідно до освітньопрофесійної або освітньо-наукової програми) мотиваційна готовність формується поетапно. Погоджуємося 3 думкою Л. М. Ємельяненко (2011), що першим, найбільш визначальним етапом, слід вважати орієнтаційний, коли студент адаптується до освітнього середовища медичного ЗВО і відбувається перше знайомство з професійним середовищем. Цілепокладанням цього етапу $є$ формування установки на освоєння базових знань та професійну самоідентифікацію, усвідомлення соціальної значущості фаху і визначення власного місця у медичній галузі та ін. На даному етапі від уявлення про фах поглиблюється інтерес до нього і потреба у професійних знаннях і уміннях, бажання досягти високого рівня компетентності у професії.

Синергетичний (гносеологічно-праксеологічний) обумовлений накопиченням і розбудовою системи знань, умінь, навичок, формування відповідних загальних і фахових компетентностей. У цей період відбувається зближення навчальної мотивації з мотивами професійної діяльності за рахунок накопичення власного досвіду, з'являються нові мотиви, інтереси і потреби, зростає рівень відповідальності на основі самооцінки рівня своєї професійної підготовки та виникає спроможність іï самоудосконалюватися. Мотиваційна готовність набуває особистісних ознак і трансформується у стійке психологічне утворення.

Коригуючий - на основі відбору, інтеграції мотивів формується мотивація до професійної діяльності. Самооцінка рівня професійної підготовки майбутнім лікарем на основі аналізу, синтезу, рефлексії мотивів і готовність їх реалізувати розвиває практично-орієнтований компонент - уміння планувати, розбудовувати і коригувати професійну діяльність, що є суттєвою ланкою у формуванні праксеологічної компетентності.

Беручи за основу дослідження науковців щодо визначення критеріїв оцінки та показників сформованості мотиваційної готовності як складової психологічної в залежності від особливостей фаху (Коваленко, 2020), серед домінантних виокремлено наступні: вияв інтересу до інновацій, креативність у діяльності, переживання позитивних емоційних станів, які викликані практичною роботою, прагнення самооцінити свій досвід із позиції власної практичної діяльності, рівня іiі організації з позиції праксеологічного підходу, емпатія до пацієнтів, прагнення до самоудосконалення.

Висновки. Наявність стійких професійних мотивів у абітурієнтів медичного 3ВО сприяє успішному оволодінню ними майбутньою професійною діяльністю і формуванню мотиваційної готовності до неї. Проте, беручи до уваги специфічні особливості і складність професії лікаря, науково-педагогічним працівникам медичних закладів вищої освіти слід забезпечити таку організацію освітнього процесу, яка сприятиме підвищенню інтересу до обраного фаху загалом, виникненню потреби у поглибленні і розбудові системи знань і набуттю праксеологічної компетентності на основі безперервного професійного розвитку, цілеспрямовано формувати мотиви професійної самореалізації в умовах навчання у ЗВО. Зазначене підвищить рівень професійної самореалізації у випускників.

Розкрито зміст і визначено компоненти мотиваційної готовності майбутніх магістрів стоматології (мотиви, мотивація) та етапи формування мотиваційної готовності майбутніх магістрів стоматології (орієнтаційний, синергетичний/гносеологічний-праксеологічний, корегуючий). Встановлено, що мотивація до професійної діяльності майбутніх магістрів стоматології у контексті формування праксеологічної компетентності забезпечується до вступу, але конкретизується і формується протягом періоду навчання у медичному закладі вищої освіти.

У подальших дослідженнях буде розкрито критерії і показники мотиваційної готовності майбутніх магістрів стоматології до професійної діяльності у контексті формування їхньої праксеологічної компетентності. 


\section{Список використаної літератури}

1. Гуртовенко Н. В. Мотиваційний компонент - головна складова готовності студентів до професійної діяльності. Наукові записки Національного університету «Острозька академія». Серія: Психологія і педагогіка. 2014. Вип. 30. С. 55-58. URL: http://nbuv.gov.ua/UJRN/Nznuoapp_2014_30_13 (дата звернення: 17.07.2021).

2. Емельяненко Л. М. Теоретические основы формирования мотивационной готовности к профессиональной деятельности будущих специалистов медицинского профиля. Вестник Брянского госуниверситета. Профессиональная педагогика. 2011. № 1. 127-131.

3. Корда М. М., Шульгай А. Г., Машталір А. І., Чорномидз А. В. Дистанційне навчання - вимушений захід чи вимога часу (на прикладі Тернопільського національного медичного університету імені І. Я. Горбачевського МОЗ України). Актуальні питання вищої медичної (фармацевтичної) освіти: виклики сьогодення та перспективи їх вирішення: матеріали XVIII Всеукраїнської науковопрактичної конференції в онлайн-режимі за допомогою системи Microsoft Teams (Tернопіль, 20-21 травня 2021 р.). Тернопіль : ТНМУ, 2021.592 с.

4. Клімова Д. В. Проблема мотиваційної готовності до професійної діяльності у психології. Єдність навчання і наукових досліджень - головний приниип університету: збірник наукових пращь звітно-наукової конференції викладачів університету за 2013 рік, 4-6 лютого 2014 року. Київ : НПУ імені М. П. Драгоманова, 2014. C. 133-135. URL:http://enpuir.npu.edu.ua/bitstream/123456789/6896/1/ Klimova.pdf (дата звернення 13.07.2021)

5. Коваленко О. В. Мотиваційна готовність майбутніх вихователів дітей дошкільного віку до самореалізації у професійній діяльності: критерії та показники рівня. Актуальні проблеми психотогії: збірник наукових праць Інституту психології імені Г. С. Костюка НАПН України. 2020. Том. IV. Психологія розвитку дошкільника. Вип. 16. С. 102-117.

6. Коваленко Н. П., Боброва Н. О., Ганчо О. В., Зачепіло С. В. Мотивація студентів як запорука успішного професійного розвитку. Медична освіта. 2020. № 3. С. 43-48. https://doi.org/10.11603/ me.2414-5998.2020.3.11440

7. Кульбашна Я. Формування професійної компетентності майбутніх фахівців із стоматології: теоретичні й методичні основи Київ: Компас, 2014. 415 с.

8. Кульбашна Я. А. Теоретичні та методичні основи формування професійної компетентності майбутніх фахівців із стоматології: дис. ... д-ра наук: 13.00.04. Київ: Інститут вищої освіти, 2015. 417с.

9. Кульбашна Я. А., Скрипник І. Л. Структура праксеологічної компетентності магістра із стоматології. Неперервна пробесійна освіта: Теорія і практика. 2020. №3. C. 71-77. DOI: https://doi. org/10.28925/1609-8595.2020.3.8

10. Ali K., Slade A., Kay E., Zahra D., Tredwin C. Preparedness of undergraduate dental students in the United Kingdom: a national study. British Dental Journal. 2017. № 222 (6). P. 472-477. DOI: http://doi. org/10.1038/sj.bdj.2017.272

11. Field J. C., Cowpe J. G., Walmsley A. D. The Graduating European Dentist: A New Undergraduate Curriculum Framework. European Journal of Dental Education. 2017. № 21 P. 2-10. DOI: http://doi. org/10.1111/eje.12307 2 .

12. Harzer W., Tausche E., Gedrange T. Harmonisation of Dental Education in Europe - a survey about 15 years after visitation of dental schools participating in the DentEd project. European Journal of Dental Education. 2015. № 21 (1). P. 22-27. DOI: http://doi.org/10.1111/eje.12171 11.

13. Reynolds P. A., Eaton K. A., Paganelli C., Shanley D. Nine years of DentEd - a global perspective on dental education. British Dental Journal. 2008. № 205 (4). P. 199-204. DOI: http://doi.org/10.1038/ sj.bdj.2008.698

\section{References}

Gurtovenko, N. V. (2014). Motyvacijnyj komponent - golovna skladova gotovnosti studentiv do profesijnoyi diyalnosti [Motivational component as the main constituent of students' maturity for professional activity]. Naukovi zapysky Nacionalnogo universytetu "Ostrozka akademiya». Seriya: Psykhologiya i pedagogika, 30, 55-58. URL: http://nbuv.gov.ua/UJRN/ Nznuoapp_2014_30_13 . 
Emelyanenko, L. M. (2011). Teoreticheskie osnovy formirovaniya motivacionnoj gotovnosti k professionalnoj deyatelnosti budushih specialistov medicinskogo profilya. [Theoretical basis of motivational maturity for professional activity of future specialists in medical field]. Vestnik Bryanskogo gosuniversiteta. Professionalnaya pedagogika, 1, 127-131.

Korda M. M., Shulgaj A. G., Mashtalir A. I., Chornomidz A. V. (2021). Distancijne navchannya - vimushenij zahid chi vimoga chasu (na prikladi Ternopilskogo nacionalnogo medichnogo universitetu imeni I. Ya. Gorbachevskogo MOZ Ukrayini). [Is distant learning obliged way or contemporary demand? (on the example of Ternopil National Medical University named after I. Horbachevskiy)]. Aktualni pitannya vishoyi medichnoyi (farmacevtichnoyi) osviti: vikliki sogodennya ta perspektivi yih virishennya: materiali XVIII Vseukrayinskoyi naukovo-praktichnoyi konferenciyi $v$ onlajnrezhimi za dopomogoyu sistemi Microsoft Teams (Ternopil, 20-21 travnia 2021 r.). TNMU.

Klimova, D. V. (2014). Klimova D. V. Problema motivacijnoyi gotovnosti do profesijnoyi diyalnosti u psihologiyi [The problem of motivational maturity for professional activity in psychology]. In Yednist navchannya i naukovih doslidzhen - golovnij princip universitetu: zbirnik naukovih prac zvitnonaukovoyi konferenciyi vikladachiv universitetu za 2013 rik, 4-6 lyutogo 2014 roku (pp. 133-135). NPU imeni M. P. Dragomanova. http://enpuir.npu.edu.ua/bitstream/123456789/6896/1/ Klimova.pdf

Kovalenko, O. V. (2020). Motivacijna gotovnist majbutnih vihovateliv ditej doshkilnogo viku do samorealizaciyi u profesijnij diyalnosti: kriteriyi ta pokazniki rivnya [Motivational maturity of future teachers of preschool children for fulfillment in professional activity]. Aktualni problemi psihologiyi: zbirnik naukovih prac Institutu psihologiyi imeni G. S. Kostyuka NAPN Ukrayini. Psihologiya rozvitku doshkilnika, IV (16), 102-117.

Kovalenko, N. P., Bobrova, N. O., Gancho, O. V., Zachepilo, S. V. (2020). Motivaciya studentiv yak zaporuka uspishnogo profesijnogo rozvitku [Students' motivation as a guarantee of successful professional development]. Medichna osvita, 3, 43-48. https://doi.org/10.11603/me.2414-5998.2020.3.11440

Kulbashna, Ya. (2014). Formuvannya profesijnoyi kompetentnosti majbutnix faxivciv iz stomatologiyi: teoretychni $j$ metodychni osnovy [Future dentists' professional competence formation: theoretical and practical bases]. Kompas.

Kulbashna, Ya. A. (2015). Teoretychni ta metodychni osnovy formuvannya profesijnoyi kompetentnosti majbutnix faxivciv iz stomatologiyi [Theoretical and practical bases of future dentists' professional competence formation]: Doctor's thesis: 13.00.04. Institut vishoyi osviti.

Kulbashna, Ya. A., Skrypnyk, I. L. (2020). Struktura prakseologichnoyi kompetentnosti magistra iz stomatologiyi [The structure of master's in dentistry praxeological competence]. Continuing professional education: theory and practice, 3, 71-77. https://doi.org/10.28925/1609-8595.2020.3.8

Ali, K., Slade, A., Kay, E., Zahra, D., Tredwin, C. (2017). Preparedness of undergraduate dental students in the United Kingdom: a national study. British Dental Journal, 222 (6), 472-477. http://doi. org/10.1038/sj.bdj.2017.272

Field, J. C., Cowpe, J. G., Walmsley, A. D. (2017). The Graduating European Dentist: A New Undergraduate Curriculum Framework. European Journal of Dental Education, 21, 2-10. http://doi.org/10.1111/ eje.12307 2.

Harzer, W., Tausche, E., Gedrange, T. (2015). Harmonisation of Dental Education in Europe - a survey about 15 years after visitation of dental schools participating in the DentEd project. European Journal of Dental Education, 21 (1), 22-27. doi.org/10.1111/eje.12171 11.

Reynolds, P. A., Eaton, K. A., Paganelli, C., Shanley, D. (2008). Nine years of DentEd - a global perspective on dental education. British Dental Journal, 205 (4), 199-204. http://doi.org/10.1038/ sj.bdj. 2008.698 


\title{
KSZTAŁTOWANIE KOMPETENCJI PRAKTYKOLOGICZNYCH MISTRZÓW STOMATOLOGII: KOMPONENT MOTYWACYJNY
}

\author{
Skrypnyk Iryna \\ ORCID iD 0000-00023-3393-4649 \\ Kandydat nauk medycznych, Profesor nadzwyczajny Katedry Ortodoncji \\ i propedeutyka stomatologii ortopedycznej. Narodowy Uniwersytet Medyczny im. O. O. Bogomolca \\ 13 bulwar T. Szewczenki, 01601 Kijów, Ukraina, \\ irynaskrypnyk@gmail.com \\ Kulbaszna Jarosława \\ ORCID iD 0000-0002-2571- 091X \\ Doktor nauk pedagogicznych, Doktor nauk medycznych, Profesor, \\ Profesor Katedry Chirurgii Szczękowo-Twarzowej, \\ Narodowy Uniwersytet Medyczny im. O. O. Bogomolca \\ 13 bulwar T. Szewczenki, 01601 Kijów, Ukraina, \\ j.kulbashna@gmail.com \\ Zacharowa Waleria \\ ORCID iD 0000-0002-8863-2373 \\ Kandydat nauk pedagogicznych, wykładówczyni Katedry Języków Obcych, \\ Narodowy Uniwersytet Medyczny im. O. O. Bogomolca, \\ 13 bulwar T. Szewczenki, 01601 Kijów, Ukraina, \\ valerieozakharova@gmail.com
}

Artykuł ujawnia treść, identyfikuje składniki i etapy rozwoju gotowości motywacyjnej przyszłych mistrzów stomatologii do aktywności zawodowej w kontekście kształtowania kompetencji prakseologicznych. Koncepcja gotowości motywacyjnej przyszłych mistrzów stomatologii do aktywności zawodowej jako dynamicznej edukacji osobistej, charakteryzującejsiękształtowaniem cech ważnychzawodowo, stabilnościmotywówwewnętrznych wyboru zawodu i ostatecznych celów szkolenia oraz zewnętrznych — atrakcyjności zawód w kontekście samowystarczalności i profesjonalizmu. Scharakteryzowano motywacyjne i prakseologiczne komponenty gotowości przyszłych mistrzów stomatologii, w szczególności przedstawiono wyniki ankiety wśród absolwentów wydziału stomatologicznego NMU im. 0.0. Bogomolca, którzy zidentyfikowali zestaw motywów, które przyczyniajq się do kształtowania gotowości do wykonywania czynności praktycznych. Ujawniane sq orientacyjne, synergiczne i korekcyjne etapy gotowości motywacyjnej przyszłych mistrzów stomatologii. Udowodniono, że obecność stabilnych motywów zawodowych u przyszłych stomatologów przyczynia się do ich pomyślnego opanowania przyszłej aktywności zawodowej i kształtowania do niej motywacyjnej gotowości.

Słowa kluczowe: gotowość motywacyjna; kompetencje prakseologiczne; działalność zawodowa; profesjonalna samorealizacja; kompetencje zawodowe.

\section{FORMATION OF PRACTICEOLOGICAL COMPETENCE OF MASTERS OF DENTISTRY: MOTIVATIONAL COMPONENT}

\author{
Skrypnyk Iryna \\ ORCID iD 0000-00023-3393-4649
}

$\mathrm{PhD}$ in Medicine, associate professor of Orthodontia and Propaedeutics of Prosthetic Dentistry department, Bogomolets National Medical University,

13 T. Shevchenko Blvd., 01601, Kyiv, Ukraine, irynaskrypnyk@gmail.com

Kulbashna Yaroslava

ORCID iD 0000-0002-2571- 091X

Doctor of Pedagogical Science, PhD in Medicine, Professor, Professor of Oral 
and Maxillofacial Surgery Department, Bogomolets National Medical University,

13 T. Shevchenko Blvd., 01601, Kyiv, Ukraine

j.kulbashna@gmail.com

Zakharova Valeriia

ORCID iD 0000-0002-8863-2373

$\mathrm{PhD}$ in Pedagogy, Teacher at Foreign Languages' Department.

Bogomolets National Medical University,

13 T. Shevchenko Blvd., 01601, Kyiv, Ukraine

valerieozakharova@gmail.com

The article deals with the content of motivational maturity for professional activity of future masters in terms of praxeological competence development. The manuscript also identifies the components and stages of its development. The notion of motivational maturity of future masters in dentistry is defined as a dynamic personal feature, characterized by the development of professionally important qualities, the stability of internal motives for choosing job and the ultimate goals of professional training and external ones like the attractiveness of job in the context of person's life support and professional fulfillment. The motivational and praxeological components of future masters' in dentistry maturity are characterized. Besides, the article presents the results of the survey among the graduates of the dental faculty of Bogomolets National Medical University. It identified a set of motives that contribute to the maturity for performing practical activities. The orientational, synergetic and corrective stages of formation of motivational maturity for future masters in dentistry are revealed. The first one - orientational stage ofprofessionalmaturityisestablished as the mostimportantoneas itoccurs when astudentadapts to aneweducational environment of a medical university. The next synergetic stage is characterized by accumulation of knowledge and skills necessary for professional competence formation when contingence of training motivation and professional one occurs. The last corrective stage deals with motivation to professional activity based on the integration of motives. It is proved that the presence of stable professional motives in future dentists contributes to their successful mastery of future professional activity and the formation of motivational maturity for it.

Keywords: motivational maturity; professional activity; motivational field; professional competences; praxeological competence. 